\title{
WHEN AND FOR WHICH PATIENTS SHOULD WE PERFORM ILEAL INTUBATION AND ILEAL BIOPSY DURING COLONOSCOPY
}

\author{
Akturk Remzi, ${ }^{1}$ Serinsoz Serdar ${ }^{2}$ \\ ${ }^{1}$ Department of Surgery, Istanbul Gelisim University, Avcılar, Istanbul, Turkey \\ ${ }^{2}$ Department of Medical Imaging, Beykent University, Turkey
}

Primljen/Received 04. 01. 2021. god.

Abstract: Background: Terminal ileum intubation(TI) is an important part of a colonoscopy. In this study, we investigated whether patients should be selected according to their symptoms rather than taking a biopsy from all of them, or whether biopsies should be taken from patients with visual pathology only detected in the mucosa.

Material and methods: Between 2008 and 2018, patients who underwent colonoscopy and ileal biopsy in our Endoscopy Unit were investigated. We evaluated patients with right iliac fossa pain, diarrhoea, and anaemia as well as patients with a high incidence of suspected inflammatory bowel disease (IBD) and high ileal abnormality in patients undergoing colonoscopy (group A). Patients with other indications were included in another group (Group B).

Results: A total of 479 patients were planned for TI according to their symptoms and colonoscopy was performed. Both microscopic and macroscopic findings were found to be more prevalent in patients with right iliac fossa pain, diarrhoea (group A), and rectal bleeding, and significantly different from patients with other symptoms (group B) $(\mathrm{p}<0.05)$.

Conclusion: We recommend that patients undergoing colonoscopy with gastrointestinal complaints also undergo ileoscopy as much as possible and that blind biopsies be taken, at least in patients with symptoms suggestive of IBD even if the mucosa is macroscopically normal. The negative results we found strengthened the diagnosis of Irritable Bowel Syndrome (IBS) and made it easier for us to proceed with IBS treatment.

Key words: Colonoscopy, ileal biopsy, ileal intubation, ileocolonoscopy, terminal ileum.

\section{INTRODUCTION}

Colonoscopy is an imaging modality that plays an important role in the diagnosis of many diseases. Ter-
Prihvaćen/Accepted 21. 02. 2021. god.

minal ileum intubation (TI) is also an important part of this examination (1). With successful TI, ileoscopy has become an important part of colonoscopy, especially in patients with inflammatory bowel disease, diarrhoea, small bowel lymphoma, cytomegalovirus (CMV), and tuberculosis ileitis (2-5). In ideal routine intubations, rare small bowel tumors such as carcinoids can also be detected (6). Furthermore, it is suggested that TI may be useful for the diagnosis of portal hypertension because hyperplasia is accompanied by hypertensive gastropathy and colopathy in a third of patients with portal hypertension (7). Ileal imaging and/or ileal biopsy (IB) is the best proof for TI such as colonic tenia unification (triradiate fold), appendiceal orifice, and ileocecal valve (ICV) photographs which are signs of arriving at the cecum suggested by the American Society of Gastrointestinal Endoscopy (ASGE) (3). Thus, it is shown that the colonoscopy was done completely. Otherwise, there may be serious diagnostic errors if one is not sure whether the colonoscopy was done properly, which would result in disadvantages for the patient. ICV intubation depends on factors primarily such as endoscopist experience and secondly colon cleansing, ICV morphology, patient age, sex, body mass index, diverticulosis, and past abdominopelvic operations and can be performed in $80-95 \%$ of patients (8). In our study, intussusception was difficult due to inadequate bowel cleansing and the anatomic placement of the ileocecal valve (9). However, when we detected ileocecal lips, we performed intubation using biopsy forceps as a guide in case of intubation difficulties (10). Sublingual glyceryl trinitrate is known to be used to facilitate Oddi cannulation in endoscopic retrograde cholangiopancreatography (ERCP). Hill PA and colleagues did not observe the difference between the two groups in their study with 800 micrograms of sublingual glyceryl trinitrate and $0.9 \%$ saline solution 
before the procedure, and they attributed TI to the endoscopist's experience (11). Willcock and colleagues suggested that arriving at the cecum and intubating the ICV is easier in the modified lithotomy (supine) position than in the left lateral position (12). Some investigations have suggested that inflation of water and $\mathrm{CO} 2$ instead of air during colonoscopy in patients, especially with inflammatory bowel disease, will provide better post-procedural comfort, easier procedure, and easier TI $(13,14)$. The lack of image clarity in colonoscopy with water may increase the risk of colon perforation especially in patients with diverticulosis. Clark and colleagues suggested that ileum mucosa is also detected in ICV biopsies without TI but also agree that TI and IB are required (15). There are also studies showing that ileal imaging is more important than cecal imaging in confirming complete colonoscopy (16). However, IB is better for understanding complete colonoscopies, but if there is no visual pathology in the ileal mucosa, it is debated whether to take the biopsy from the ileum because the pathology detection rate is low $(0.3-7 \%)$. However, in the current approach, the appearance of villus structure with TI is considered sufficient to demonstrate the completion of colonoscopy. The same investigations find routine IB unnecessary in patients with normal ileal mucosa, except for patients who are undergoing control colonoscopy because of inflammatory bowel disease $(17,18,19)$. In this study, we investigated whether patients should be selected according to their symptoms rather than taking a biopsy from all of them, or whether biopsies should be taken from patients with visual pathology only detected in the mucosa.

\section{MATERIAL AND METHODS}

Between 2008 and 2018, patients who underwent colonoscopy and IB at the SAFA Hospital Group Endoscopy Unit (Istanbul/Turkey) with abdominal pain, chronic diarrhoea, chronic constipation, anaemia, rectal bleeding, weight loss, and proctological complaints were retrospectively reviewed. Clinical data and details of the histopathological diagnoses were obtained from the endoscopy database and patient records. We evaluated patients with right iliac fossa (RIF) pain, diarrhoea, and anaemia as patients with a high incidence of suspected IBD (Inflammatory Bowel Disease) and high ileal abnormality in patients undergoing colonoscopy (group A). Patients with other indications formed the other group (group B). They were evaluated for macroscopically significant findings of ulceration, erosion, stenosis, or inflammation on colonoscopy in the terminal ileum. The only nodularity in the distal ileum mucosa was accepted as a macroscopically nonspecific finding and recorded as a routine biopsy $(20,21)$.
Attempts were made to take biopsies from lesions at least $5 \mathrm{~cm}$ distal to the lesions. Chronic nonspecific ileitis, oedema, hyperaemia, and lymphoid hyperplasia were accepted as nonspecific findings and evaluated as pathologically meaningless. Cases with active chronic ileitis, structural distortion, erosion, ulceration, cryptitis, crypt abscess, fibrosis, and Paneth cell hyperplasia were considered microscopically significant (21).

Post-biopsy pain complaining patients were evaluated by the radiology medical imaging department for determining possible complications and avoiding unnecessary surgical procedures.

\section{Statistical analysis}

The data were arranged as SPSS 18 data, and it was determined that the data were not normally distributed as a result of the measurements of skewness and kurtosis. As a result, mean, standard deviation, range, minimum and maximum values, and percentage were measured for the parameters of ileal intubation time. Symptom parameters were tested with the Kruskal-Wallis test for ileal pathology. Also, two groups with significant differences were compared again with the Mann-Whitney U test. A $P$ value of $<0.05$ was taken as statistically significant. However, the two groups with macroscopic and microscopic findings were also assessed with a correlation between themselves. All procedures performed were with the standard of the institutional research ethics committee and the 1964 Helsinki declaration and its later amendments.

\section{Availability of data and materials}

The data that support the findings of this study are available from SAFA Hospital Group but restrictions apply to the availability of these data, which were used under license for the current study, and so are not publicly available. Data are, however, available from the authors upon reasonable request and with permission of SAFA Hospital Group.

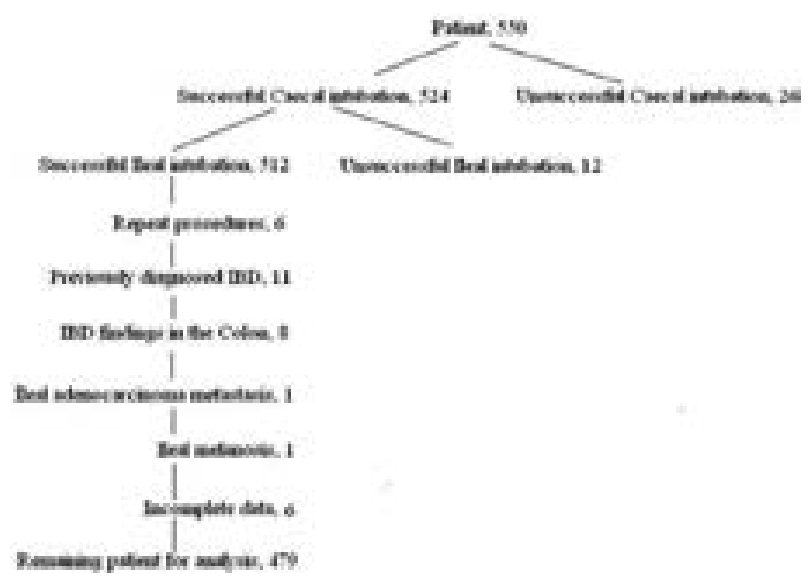

Figure 1. Patient selection 


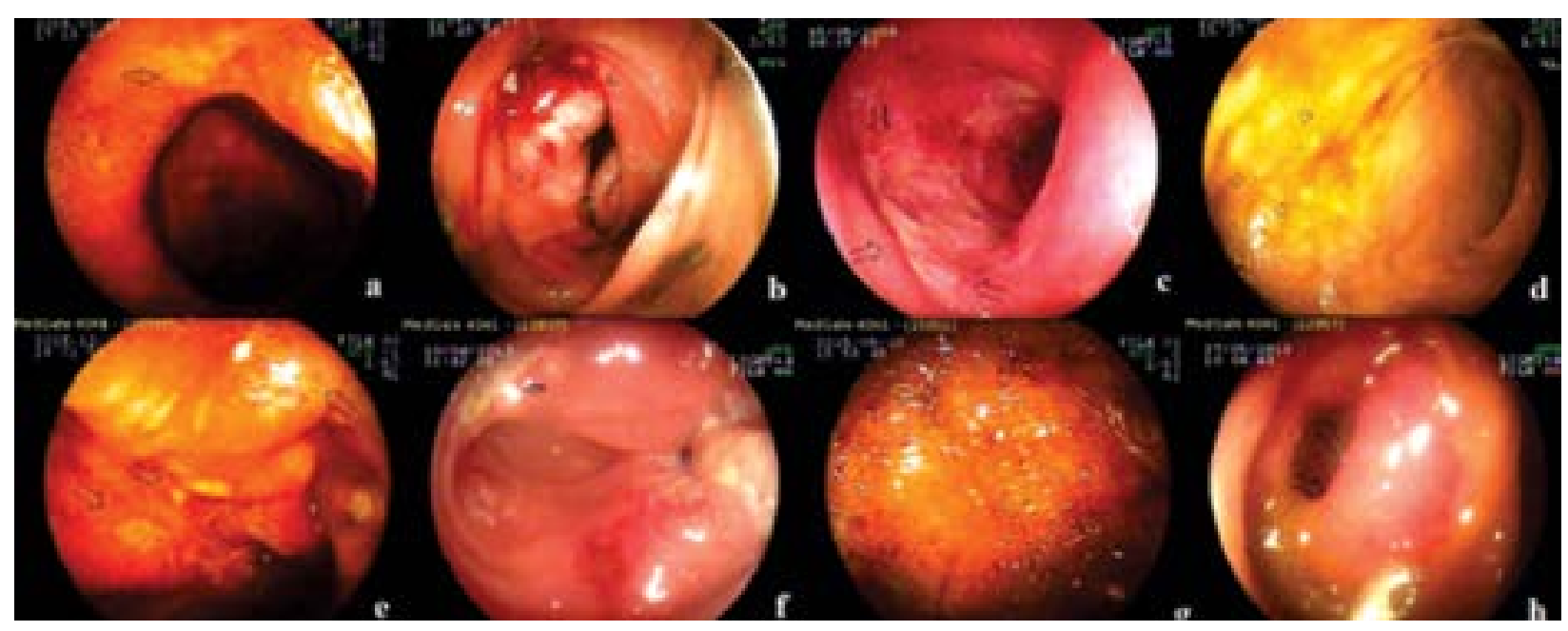

Figure 2. Macroscopic abnormality of ileum; backwash ileitis (a, b, c), nodular ileitis (lymphoid hyperplasia, d), Crohn disease (CD) (e, f), ileal melanosis $(g)$, ileal adenocarcinoma metastasis $(h)$

\section{RESULTS}

Of the 5146 colonoscopies performed in 10 years, 550 patients with TI planned and applied according to their symptoms were evaluated.

The cecum was reached in the majority of patients (524/550, 95.27\%). Only 22 patients had insufficient bowel cleansing, 3 patients had morbid obesity, and 1 patient had late adhesions due to recurrent abdominal surgery. Therefore, the cecum could not be reached in these patients. Almost all of the patients underwent TI (512/524, 97.71\%). 33 patients were excluded from the study because inflammatory bowel disease macroscopic findings were detected in the colon (8/33), IBD was detected before (11/33), adenocarcinoma metastasis was detected in the pathology $(1 / 33)$, ileal melanosis was present (1/33), and the procedure was repeated (6/33), or incomplete data (6/33) (Figure 1, Figure 2). For this reason, only $479 / 550$ patients were included in the study. The mean age of the patients was $40.80 \pm$ 14.807 (14-84) years and there was no significant difference between macroscopic findings and microscopic findings according to age $(\mathrm{P}>0.05)$. The mean TI time of $3.16 \pm 2.078(1-15)$ was observed. There was no significant difference in terms of TI time between male and female patients $(\mathrm{p}>0.05)$.
As seen in Table 1, the incidence of macroscopic findings was significantly higher in males than in females $(\mathrm{P}<0.05)$.

As seen in Table 2, the incidence of macroscopic findings on colonoscopy was the same as microscopic findings in constipated patients $(\mathrm{p}>0.05)$. Both microscopic and macroscopic findings were found to be more prevalent in patients with RIF pain, diarrhoea, and rectal bleeding, and significantly different from patients with other symptoms $(\mathrm{p}<0.05)$. Microscopic findings and macroscopic findings can be seen together, and most microscopic findings are not accompanied by macroscopic findings $(\mathrm{P}<0.05)$. Although there are more macroscopic findings in patients with proctologic symptoms, microscopic findings do not accompany this finding $(\mathrm{p}>0.05)$.

As seen in table 3, microscopic pathology was observed in $70.3 \%(78 / 111)$ of the patients with macroscopic pathology, while macroscopic pathology was detected in $36.97 \%(78 / 211)$ of the patients with microscopic pathology. A weak correlation was found between macroscopic findings and microscopic findings ( $r$ : 0.290). As expected, there is a positive correlation between macroscopic findings and microscopic findings $(p>0.05)$.

Table 1. Ileal pathology distribution according to gender

\begin{tabular}{|c|c|c|c|c|c|c|c|c|c|c|}
\hline \multirow{3}{*}{ Gender } & \multicolumn{9}{|c|}{ Ileal Pathology } \\
\cline { 2 - 13 } & \multicolumn{2}{|c|}{ Normal } & \multicolumn{2}{|c|}{ Mac. Signs } & \multicolumn{2}{|c|}{ Mic. Signs } & \multicolumn{2}{c|}{$\begin{array}{c}\text { Mac.\&Mic. } \\
\text { Signs }\end{array}$} & \multicolumn{2}{c|}{ Total } \\
\cline { 2 - 13 } & $\mathbf{n}$ & $\mathbf{\%}$ & $\mathbf{n}$ & $\mathbf{\%}$ & $\mathbf{n}$ & $\mathbf{\%}$ & $\mathbf{n}$ & $\mathbf{\%}$ & $\mathbf{n}$ & $\mathbf{\%}$ \\
\hline Woman & 125 & 26.1 & 9 & 1.9 & 57 & 11.9 & 34 & 7.1 & 225 & 47.0 \\
\hline Man & 110 & 23.0 & $\mathbf{2 4}$ & $\mathbf{5 . 0}$ & 76 & 15.9 & 44 & 9.2 & 254 & 53.0 \\
\hline Total & 235 & 49.1 & 33 & 6.9 & 133 & 27.8 & 78 & 16.3 & 479 & 100 \\
\hline
\end{tabular}


Table 2. Distribution of macroscopic and microscopic findings between symptoms

\begin{tabular}{|c|c|c|c|c|c|c|c|c|c|c|}
\hline \multirow{3}{*}{$\begin{array}{l}\text { Major indication } \\
\text { for colonoscopy }\end{array}$} & \multicolumn{10}{|c|}{ Ileal Pathology } \\
\hline & \multicolumn{2}{|c|}{ Normal } & \multicolumn{2}{|c|}{ Mac. Signs } & \multicolumn{2}{|c|}{ Mic. Signs } & \multicolumn{2}{|c|}{$\begin{array}{l}\text { Mac.\&Mic. } \\
\text { Signs }\end{array}$} & \multicolumn{2}{|c|}{ Total } \\
\hline & $\mathrm{n}$ & $\%$ & $\mathrm{n}$ & $\%$ & $\mathrm{n}$ & $\%$ & $\mathrm{n}$ & $\%$ & $\mathrm{n}$ & $\%$ \\
\hline \multicolumn{11}{|l|}{ Group A } \\
\hline RIF Pain & 14 & 2.9 & 1 & 0.2 & 62 & 12.9 & 32 & 6.7 & 109 & 22.8 \\
\hline diarrhoea & 11 & 2.3 & 2 & 0.4 & 29 & 6.1 & 15 & 3.1 & 57 & 11.9 \\
\hline anaemia & 10 & 2.1 & 0 & 0 & 1 & 0.2 & 0 & 0 & 11 & 2.3 \\
\hline Subtotal & 35 & 7.3 & 3 & 0.6 & 94 & 19.6 & 47 & 9.8 & 179 & 37.4 \\
\hline \multicolumn{11}{|l|}{ Group B } \\
\hline $\begin{array}{l}\text { Nonspecific } \\
\text { abdominal pain }\end{array}$ & 32 & 6.7 & 2 & 0.4 & 3 & 0.6 & 0 & 0 & 41 & 8.6 \\
\hline Constipation & 101 & 21.1 & 17 & 3.5 & 17 & 3.5 & 16 & 3.3 & 151 & 31.5 \\
\hline Rectal Bleeding & 12 & 2.5 & 3 & 0.6 & 16 & 3.3 & 11 & 2.3 & 42 & 8.8 \\
\hline Proctological Symptoms & 46 & 9.6 & 7 & 1.5 & 4 & 0.8 & 3 & 0.6 & 60 & 12.5 \\
\hline Weight Loss & 7 & 1.5 & 0 & 0 & 2 & 0.4 & 1 & 0.2 & 10 & 2.1 \\
\hline Subtotal & 200 & 41.8 & 30 & 6.3 & 39 & 8.1 & 31 & 6.5 & 300 & 62.6 \\
\hline Total & 235 & 49.1 & 33 & 6.9 & 133 & 27.8 & 78 & 16.3 & 479 & 100 \\
\hline
\end{tabular}

Table 3. Crosstab comparison of macroscopic and microscopic findings

\begin{tabular}{|c|c|c|c|c|c|}
\hline & \multicolumn{2}{|c|}{ Microscopic pathology } & \multirow{2}{*}{ Total } \\
\hline & & & Absent & Present & \\
\hline \multirow{6}{*}{$\begin{array}{c}\text { Macroscopic } \\
\text { pathology }\end{array}$} & \multirow{3}{*}{ Absent } & Count & 235 & 133 & 368 \\
\hline & & Expected Count & 205.9 & 162.1 & 368.0 \\
\hline & & \% within macroscopic pathology & $63.9 \%$ & $36.1 \%$ & $100.0 \%$ \\
\hline & \multirow{3}{*}{ Present } & Count & 33 & 78 & 111 \\
\hline & & Expected Count & 62.1 & 48.9 & 111.0 \\
\hline & & \% within macroscopic pathology & $29.7 \%$ & $70.3 \%$ & $100.0 \%$ \\
\hline \multirow{3}{*}{\multicolumn{2}{|c|}{ Total }} & Count & 268 & 211 & 479 \\
\hline & & Expected Count & 268.0 & 211.0 & 479.0 \\
\hline & & \% within macroscopic pathology & $55.9 \%$ & $44.1 \%$ & $100.0 \%$ \\
\hline
\end{tabular}

Table 4. Distribution of disease between the groups

\begin{tabular}{|l|c|c|c|c|c|c|}
\hline \multirow{2}{*}{ Disease } & \multicolumn{6}{|c|}{ Group } \\
\cline { 2 - 7 } & \multicolumn{2}{|c|}{ Group A } & \multicolumn{2}{c|}{ Group B } & \multicolumn{2}{c|}{ Total } \\
\cline { 2 - 7 } & $\mathbf{n}$ & $\mathbf{\%}$ & $\mathbf{n}$ & $\mathbf{\%}$ & $\mathbf{n}$ & \% \\
\hline IBS & 38 & $7.9 \%$ & 230 & $48.0 \%$ & 268 & $55.9 \%$ \\
\hline Crohn disease & 22 & $4.6 \%$ & 9 & $1.9 \%$ & 31 & $6.5 \%$ \\
\hline TBC & 2 & $0.4 \%$ & 0 & $0.0 \%$ & 2 & $0.4 \%$ \\
\hline Infection & 94 & $19.6 \%$ & 47 & $9.8 \%$ & 141 & $29.4 \%$ \\
\hline Drug & 23 & $4.8 \%$ & 14 & $2.9 \%$ & 37 & $7.7 \%$ \\
\hline Total & 179 & $37.4 \%$ & 300 & $62.6 \%$ & 479 & $100.0 \%$ \\
\hline
\end{tabular}




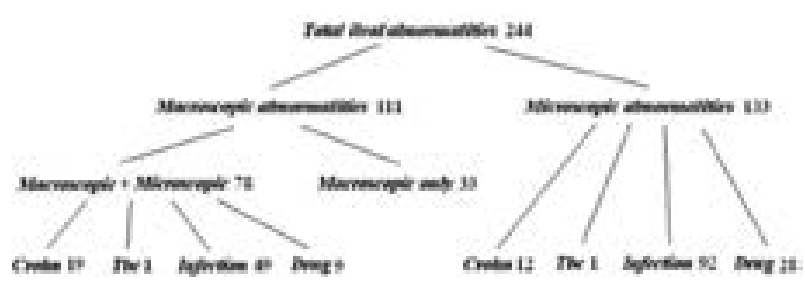

Figure 3. Distribution of ileal pathology and disease

When microscopic abnormalities are examined according to pathologies, drug use and abuse play an important role in infection (94/179) accounted for $19.6 \%$ of the patients in group A, while patients with irritable bowel syndrome (IBS) (230/300) accounted for $48 \%$ of group B. Drugs are especially important in both groups. This rate is close to inflammatory bowel diseases (Table 4, Figure 3).

\section{DISCUSSION}

In the vast majority of patients, the cecum was reached $(524 / 550,95.27 \%)$ and TI was performed in almost all patients $(512 / 524,97.71 \%)$. In different studies, it was reported that the rate of access to the cecum is $93.6 \%$ to $99 \%$ and the rate of TI is $87 \%$ to $97 \%$ $(8,9,16,22)$. We found that the mean TI time was 3.16 \pm 2.078 (1-15) in our study. The incidence of macroscopic findings was significantly higher in males than in females $(p<0.05)$. In a study conducted in 2005 , it was reported that many factors such as colon resection surgery and experienced endoscopy staff shortened the TI time, but most importantly, the large intestine must be adequately cleaned. In the same study, the meantime to reach the cecum was $10.5 \pm 10.2 \mathrm{~min}(9)$. The mean TI duration was reported to be between 1 and 6.4 minutes, depending on the endoscopy team and patient-related factors $(8,9,16)$. In our study, the experience of the colonoscopist, the technical characteristics of the device (especially the relaxation of the rotation mechanism over time), and the additional manoeuvre experience of the endoscopy nurse were factors that related to the procedure affecting the TI time. Morbid obesity, a previous abdominal operation, and most importantly, adequate bowel cleansing were the patient-related factors. There was no significant difference between male and female patients in terms of TI time ( $p>0.05)$. While microscopic findings are detected with symptoms of IBD such as RIF pain, diarrhoea, and rectal bleeding, macroscopic findings may not accompany these microscopic findings. The reason for this may be that every patient can easily undergo colonoscopy nowadays so that the disease can be detected during the remission phase. Some studies have identified mucosal macroscopic pathology rate as $1.35 \%$ and histopathologic pathology rate as $0.33 \%$ in randomised IB cases, suggesting that routine TI is not necessary $(17,23)$. Kunrotas LW and colleagues showed that the diagnostic value of TI and IB is low if the colon is normal in colonoscopies performed in patients with chronic diarrhoea without rectal bleeding (17). A positive diagnosis rate is given as $2.7-5 \%$ with TI and IB in asymptomatic patients, and some studies suggest that TI is an important aid for colonoscopy, especially in diarrhoeal patients $(18,24)$. In our study, we found macroscopic and microscopic findings in patients with constipation and proctologic complaints, although there were no symptoms suggestive of IBD. Some studies have shown that patients with symptoms suggestive of IBD have a significantly higher incidence of histological ileal abnormalities than others $(1,2,18,25)$.

In some of the patients without macroscopic findings, microscopic findings appeared, which weakens the correlation between macroscopic findings and microscopic findings (r: 0,290). Misra SP and colleagues found that histological examination of biopsies taken from the normal-looking cecum and terminal ileum was useful in a small but significant number of patients with colonic tuberculosis (5). In some studies, histopathologic abnormalities were detected in 27/764 patients $(3.53 \%)$ despite endoscopically normal terminal ileum. Of these patients, $82.46 \%$ did not have mucosal abnormality during endoscopy. However, significant ileal abnormality (Crohn's Disease, inflammation, and inflammation-related) was detected by TI and IB in $1.9 \%$ of these patients. They suggested that these patients who did not undergo TI and IB could not be diagnosed and that it could lead to misdiagnosis during diagnosis and treatment (2). Makkar L. et al. found the diagnostic values of TI and IB are low if the colon mucosa is normal during endoscopies in patients with chronic, non-bloody diarrhoea. However, they suggested that TI and IB may provide supportive evidence for patients with previously diagnosed ileocolonic Crohn's disease (21). Borcsh G et al. (19) proposed routine TI in all patients undergoing a colonoscopy as a diagnostic procedure with suspected or identified inflammatory bowel disease and/or persistent diarrhoea, lower gastrointestinal tract bleeding or IBS (19). Another study showed that TI has a high diagnostic yield and this study found 14\% (8/57) of ileal abnormalities in patients with normal colonoscopy or barium enema (25).

While the negative results distanced us from IBD diagnosis, they brought us closer to IBS diagnosis and made it easier for us to proceed with IBS treatment. In a multicentre study, it was suggested that TI and IB should be an integral part of colonoscopy in patients with RIF pain, diarrhoea, anaemia, suspected 
IBD, or elevated inflammatory markers. In this group of patients, even if the macroscopic appearance of the colon and the terminal ileum are sometimes normal, $\mathrm{TI}$ and IB can provide additional information for the colonoscopy diagnostic findings and effects. Also, TI and IB are relatively easy and there is no risk of additional adverse effects. However, they did not find strong enough evidence to recommend routine use in all cases, and they found that the diagnostic yield was low in patients without suspected IBD. Thus, in addition, they considered that the cost of routine ileal histology may be another disadvantage (2). Some studies suggest TI and IB in symptomatic patients as a diagnostic procedure for suspected or diagnosed IBD, IBS with chronic diarrhoea, and lower GI bleeding. In particular, they suggested that the nonpathological emergence of IB as a diagnostic procedure for IBS has diagnostic value in terms of showing the absence of organic pathologies $(19,22)$. Kundrotas LW and colleagues suggest that TI and IB should be performed in colonoscopies for screening purposes, although the detection rate of abnormal microscopic findings is too low to be considered, as TI and IB do not lead to time and cost loss (23).

When microscopic abnormalities are examined according to pathologies, drug use and abuse play an important role. Infections (94/179) accounted for $19.6 \%$ of the patients in group A, while IBS patients (230/300) accounted for $48 \%$ of group B. Drugs are especially important in both groups. This rate is close to inflammatory bowel diseases (Table 4). The similarity of inflammatory bowel disease and microscopic ileal pathology with drug use may also be the subject of a separate study. Kennedy $\mathrm{G}$ and colleagues showed poor abnormal macroscopic ileal findings in only $1 \%$ of patients and microscopic ileal abnormalities were detected in only $0.3 \%$ of all patients; thus, suggesting that TI should not be a necessary part of the screening colonoscopy (23). Mohammad Hassan Emami et al. stated that normal ileal findings in TI pathology + helped to exclude IBD in diagnosis in 78 patients with abdominal pain, weight loss, low GI bleeding, or colonic inflam- mation, and in this study 82 patients $(86.3 \%)$ showed that TI and IB were clinically valuable findings. TI is safe, fast and feasible; therefore, it is recommended in all symptomatic cases since normal findings are valuable in the clinical management of patients. Given normal findings, they came to the conclusion that routine TI has a surprisingly high diagnostic yield compared to the results of previous studies (22).

\section{CONCLUSION}

As a result, we recommend that patients undergoing colonoscopy with gastrointestinal complaints undergo ileoscopy as much as possible and that blind biopsies be taken, at least in patients with symptoms suggestive of IBD even if the mucosa is macroscopically normal. Besides, we do not believe that colonoscopy can be completed without ileoscopy. The negative results we found strengthened the diagnosis of IBS and made it easier for us to proceed with IBS treatment. These results made it possible to easily add antidepressants to IBS treatment.

Conflict of Interests: The authors declare that there are no conflicts of interest related to this article.

Funding: None

\section{Licensing}

This work is licensed under a Creative Commons Attribution 4.0 International (CC BY 4.0) License.

Ethics approval and consent to participate: The study was approved by S.B.U. Istanbul Education and Research Hospital Clinical Research Ethics Committee (Approval no: 2159).

Authors' contributions: I would like to thank Serdar SERINSOZ MD, responsible for our radiology department, for his contributions to both data and writing. All authors read and approved the final manuscript.

Acknowledgments: I would like to thank everyone who contributed to this study, especially my family and author friends.

\title{
Sažetak
}

\section{KADA I ZA KOJE PACIJENTE JE INDIKOVANA IILEOSKOPIJA I BIOPSIJA TOKOM KOLONOSKOPIJE}

\author{
Akturk Remzi, ${ }^{1}$ Serinsoz Serdar ${ }^{2}$ \\ ${ }^{1}$ Department of Surgery, Istanbul Gelisim University, Avc1lar, \\ Istanbul, Turkey \\ ${ }^{2}$ Department of Medical Imaging, Beykent University, Turkey
}


Uvod: Intubacija terminalnog ileuma (TI) važan je deo kolonoskopije. U ovoj studiji istraživali smo da li pacijente treba birati prema njihovim simptomima, bez uzimanja biopsije od svih, ili treba uzimati biopsije kod pacijenata sa vizuelnom patologijom koja je otkrivena samo na sluznici.

Metode: Između 2008. i 2018. istraživani su pacijenti koji su bili podvrgnuti kolonoskopiji i biopsiji ileusa u našoj jedinici za endoskopiju.

Ispitivali smo pacijente sa bolom $\mathrm{u}$ desnoj ilijačnoj jami, dijarejom i anemijom, kao i pacijente sa velikom učestalošću sumnje na inflamatorno oboljenje creva (IBD) i abnormalnosti ileuma kod pacijenata podvrgnutih kolonoskopiji (Grupa A). Pacijenti sa drugim indikacijama bili su uključeni u drugu grupu (grupa B).

\section{REFERENCES}

1. Misra SP, Dwivedi M, Misra V. Ileoscopy in 39 hematochezia patients with normal colonoscopy. World J Gastroenterol. 2006; 12(19): 3101-4. doi: 10.3748/wjg.v12.i19.3101.

2. Wijewantha HS, de Silva AP, Niriella MA, Wijesinghe N, Waraketiya P, Kumarasena RS, et al. Usefulness of routine terminal ileoscopy and biopsy during colonoscopy in a tropical setting: a retrospective record-based study. Gastroenterol Res Pract. 2014; 2014: 343849. doi: 10.1155/2014/343849.

3. Rex DK, Petrini JL, Baron TH, Chak A, Cohen J, Deal SE, et al. Quality indicators for colonoscopy. Gastrointest Endosc. 2006; 63(Suppl 4): S16-28. doi: 10.1016/j. gie.2006.02.021.

4. Mansuri I, Fletcher JG, Bruining DH, Kolbe AB, Fidler JL, Samuel S, et al. Endoscopic skipping of the terminal ileum in pediatric Crohn disease. AJR Am J Roentgenol. 2017; 208(6): W216-24. doi: 10.2214/AJR.16.16575.

5. Misra SP, Dwivedi M, Misra V, Gupta M, Kunwar BK.Endoscopic biopsies from normal-appearing terminal ileum and cecum in patients with suspected colonic tuberculosis. Endoscopy. 2004; 36(7): 612-6. doi: 10.1055/s-2004-814518.

6. Ten Cate EM, Wong LA, Groff WL, Miller AT. Post-surgical surveillance of locally advanced ileal carcinoids found by routine ileal intubation during screening colonoscopy: a case series. J Med Case Rep. 2014; 8:444. doi: 10.1186/17521947-8-444.

7. Rana SS, Bhasin DK, Jahagirdar S, Raja K, Nada R, Kochhar R, et al. Is there ileopathy in portal hypertension? $J$ Gastroenterol Hepatol. 2006; 21(2): 392-7. doi: 10.1111/j.14401746.2005.04037.x.

8. Iacopini G, Frontespezi S, Vitale MA, Villotti G, Bella A, d'Alba L, et al.Routine ileoscopy at colonoscopy: a prospective evaluation of the learning curve and skill-keeping line. Gastrointest Endosc. 2006; 63(2): 250-6. doi: 10.1016/j. gie.2005.09.029.

9. Zuber-Jerger I, Endlicher E, Gelbmann CM.Factors affecting cecal and ileal intubation time in colonoscopy. Med
Rezultati: Obavljeno je ukupno 479 pacijenata kojima je planirano TI u skladu sa simptomima i kolonoskopijom. Utvrđeno je da su i mikroskopski i makroskopski nalazi zastupljeniji kod pacijenata sa bolom u desnoj ilijačnoj jami, dijarejom (grupa A) i rektalnim krvarenjem i značajno se razlikuju od pacijenata sa drugim simptomima (grupa $B)(p<0,05)$.

Zaključak: Preporučujemo da se pacijenti nakon kolonoskopije sa gastrointestinalnim tegobama takođe podvrgavaju ileoskopiji što je više moguće i da se uzimaju slepe biopsije, barem kod pacijenata sa simptomima koji sugerišu IBD, čak i ako je sluznica makroskopski normalna. Negativni rezultati koje smo pronašli ojačali su dijagnozu sindroma iritabilnog creva (IBS) i olakšali nam nastavak lečenja IBS.

Ključne reči: Kolonoskopija, biopsija ileala, intubacija ileala, ileokolonoskopija, terminalni ileum.

Klin (Munich). 2008; 103(7): 477-81. doi: 10.1007/s00063008-1071-6.

10. Abdulla HM, Bachar M, Chamberlain SM. Forceps-assisted intubation of the ileocecal valve. Gastrointest Endosc. 2016; 83(3): 662-3. doi: 10.1016/j.gie.2015.09.014.

11. Hill PA, Panteleimonitis S, McKay G, Watson C, Prach A, Macdonald A. Sublingual glyceryl trinitrate during colonoscopy and terminal ileal intubation: a randomized controlled trial. Scott Med J. 2017; 62(1): 11-15. doi: 10.1177/0036933017690465.

12. Willcock H, Gold DM. Supine colonoscopy: an advantage over left lateral in synchronous proctological surgery. J. Laparoendosc Adv Surg Tech A. 2016; 26(6): 475-7. doi: 10.1089/lap.2015.0609.

13. Falt P, Šmajstrla V, Fojtík P, Urban O, Hill M. Water-aided colonoscopy in inflammatory bowel disease patients-a randomised, single-centre trial. J Crohns Colitis. 2015; 9(9): 720-4. doi: 10.1093/ecco-jcc/jjv093.

14. Falt P, Šmajstrla V, Fojtík P, Hill M, Urban O. Carbon dioxide insufflation during colonoscopy in inflammatory bowel disease patients: a double-blind, randomized, single-centre trial. Eur J Gastroenterol Hepatol. 2017; 29(3): 355-9. doi: 10.1097/ MEG.0000000000000791.

15. Clark DA, Rocker M, Reddy M, Aslam M, Owen SM. Confirmation of complete colonoscopy without intubation of the ileum. Colorectal Dis. 1999; 1(5): 283-5. doi: 10.1046/j.14631318.1999.00072.x.

16. Powell N, Knight H, Dunn J, Saxena V, Mawdsley J, Murray $\mathrm{C}$, et al. Images of the terminal ileum are more convincing than cecal images for verifying the extent of colonoscopy. Endoscopy. 2011; 43(3): 196-201. doi: 10.1055/s-00301256174 .

17. Kennedy G, Larson D, Wolff B, Winter D, Petersen B, Larson M. Routine ileal intubation during screening colonoscopy: a useful manoeuvre? Surg Endosc. 2008; 22(12): 2606-8. doi: 10.1007/s00464-008- 9843-x.

18. Zwas FR, Bonheim NA, Berken CA, Gray S. Diagnostic yield of routine ileoscopy. Am J Gastroenterol. 1995; 90(9): 1441-3. 
19. Borsch G, Schmidt G. Endoscopy of the terminal ileum. Diagnostic yield in 400 consecutive examinations. Dis Colon Rectum. 1985; 28(7): 499-501. doi: 10.1007/BF02554095.

20. Tontini GE, Vecchi M, Pastorelli L, Neurath MF, Neumann H. Differential diagnosis in inflammatory bowel disease colitis: State of the art and future perspectives. World J Gastroenterol. 2015; 21(1): 21-46. doi: 10.3748/wjg.v21.i1.21.

21. Makkar R, Lopez R, Shen B. Clinical utility of retrograde terminal ileum intubation in the evaluation of chronic non-bloody diarrhoea. J Dig Dis. 2013; 14(10): 536-42. doi: 10.1111/1751-2980.12082.

22. Emami MH, Behbahan IS, Zade HD, Daneshgar H. A new interpretation for the diagnostic yield of ileoscopy: A prospective study and a brief review. J Res Med Sci. 2009; 14(3): 157-63.
23. Kundrotas LW, Clement DJ, Kubik CM, Robinson AB, Wolfe PA.A prospective evaluation of successful terminal ileum intubation during a routine colonoscopy. Gastrointest Endosc. 1994; 40(5): 544-6. doi: 10.1016/s0016-5107(94)70249-7.

24. Annese V, Daperno M, Rutter MD, Amiot A, Bossuyt P, East J, et al. European Crohn's and Colitis Organisation. European evidence-based consensus for endoscopy in inflammatory bowel disease. J Crohns Colitis. 2013; 7(12): 982-1018. doi: 10.1016/j.crohns.2013.09.016.

25. Bhasin DK, Goenka MK, Dhavan S, Dass K, Singh K. Diagnostic value of ileoscopy: a report from India. J Clin Gastroenterol. 2000; 31(2): 144-6. doi: 10.1097/00004836200009000-00011.

\section{Correspondence to/Autor za korespondenciju}

\section{Remzi Akturk}

Address: Private Safa Hospital; Zafer Mh, Ahmet Yesevi cd. Gümüş sk No 9/11 Bahçelievler/Istanbul Mobile Phone, Phone: +90 53225356 24, 08508787232 / 2137

Email: dremzi@gmail.com

Orcid Id: 0000-0002-1951-2087 